УДК $620.9+621.315$

DOI 10.36910/6775-2313-5352-2021-18-15

Никируй Л.І. ${ }^{1}$, Замурусва О.В. ${ }^{2}$, Федосов В.С. ${ }^{2}$, Урбан О.А. ${ }^{3}$, Захарчук Д.А. ${ }^{3}$, Федосов С.А. ${ }^{2}$

${ }^{1}$ Прикарпатський національний університет імені Василя Стефаника

${ }^{2}$ Волинський національний університет імені Лесі Українки

${ }^{3}$ Луцький національний технічний університет

\title{
ПЕРСПЕКТИВНІ ТЕХНОЛОГІЇ БІОПАЛИВНОЇ ЕНЕРГЕТИКИ
}

У роботі проаналізовано публікаиії авторитетних світових науковиів $i$ з двох сусідніх держав - України та Польщі у галузі біопаливної енергетики, щоб знайти закономірності як розвитку иього напрямку у світі і кожній державі зокрема, так і визначити перспективи для спільних досліджень. Аналіз трунтується на результатах даних, опублікованих у міжнародних наукових базах даних Web of Science та Scopиs. Виявлено стан розвитку галузі у кожній країні, проаналізовано як теоретичні, так $і$ прикладні дослідження, спрямовані на практичне застосування.

Ключові слова: відновлювальні джерела енергії, енергія біопалива, біопаливо, біомаса, Украйна, Польща, $h$-індекс.

Втуп. Відсутність належної енергетичної політики серед держав, зокрема тих, економіка яких базується на викопних паливах, часто згубно впливає на навколишнє середовище. 3 цієї причини більшість держав розпочали підтримувати розвиток відновлювальних джерел енергії на законодавчому рівні та заохочувати перехід до їх широкого використання. Однак виклик такій політиці ЄС можливий через недотримання цих ініціатив державами, що межують з ЄС. Тому доцільним $є$ аналіз розвитку відновлювальної енергетики у двох сусідніх країнах Польщі та Україні.

Серед усіх відновлюваних енергетичних ресурсів одним з найбільш перспективних та стратегічно важливих $є$ біоенергетичний ресурс. Роль та значення біоенергетики для розвитку економіки неодноразово підкреслювалося у доповідях вчених, експертів, практиків, усіх тих, хто так чи інакше займається енергетичними проблемами. Україна та Польща знаходяться в схожих широтах і мають майже однакову кількість сонячних днів та схожу інфраструктуру, включаючи наукову. Наукові інститути та університети цих країн приділяли значну увагу розвитку матеріалознавства для енергетики (науки про енергетичні матеріали). Біоенергетика $\epsilon$ специфічною особливістю цих країн. Обидві країни мають розвинене сільське господарство, відходи якого є прямим джерелом біопалива або біогазу [1].

Методологія досліджень. Наукову літературу шукали в академічних бібліотеках, Web of Science, Scopus, яку рецензували англійською мовою та видавали книги. Відібрані наукові праці, що свідчать про приналежність Польщі чи України. Процедура детально описана в роботі [2]. Огляд джерел проводився на основі аналізу як найбільш важливих чи найбільш цитованих (сортування за кількістю цитат), так і останніх (сортування за датою).

Аналіз результатів. На відміну від сонячної енергетики, розвиток біоенергетики є більш специфічним і потребує наявності певних галузей економіки в країні. Україна та Польща, серед інших країн, вигідно відрізняються наявністю розвиненого сільського господарства. Відповідно, раціональна утилізація відходів біомаси із рослинництва та тваринництва $є$ дуже важливим. У той же час, поряд з екологічним питанням, частково вирішується питання генерації відновлюваної електроенергії. У сільськогосподарських регіонах обох країн активно впроваджуються різні біогазові станції. Таким чином, існує інший підхід до цієї галузі відновлювальної енергії: реалії економіки вимагають ії розвитку на новому, більш ефективному науковому рівні. А наявність спільного кордону та подібних географічних умов $\epsilon$ фактором, що створює однакові технологічні умови для розвитку біоенергетики для обох країн.

Біоенергетика тісно пов'язана $з$ поняттями «біомаса» та «біопаливо». Біомаса означає органічну речовину рослинного походження та відходи, отримані шляхом природного або штучного перетворення, які можуть бути використані в енергетичних цілях. Біопаливо - це поновлюване джерело енергії, отримане з рослинної або тваринної біомаси. Хоча в багатьох дослідженнях терміни «біомаса» та «біопаливо» використовуються взаємозамінно, ми вважаємо за доцільне їх диференціювати. Біомаса - це сировина. Тоді як біопаливо $є$ продуктом переробки біомаси.

(C) Никируй Л.І., Замурусва О.В., Федосов В.С., Урбан О.А., Захарчук Д.А., Федосов С.А. 
Біопаливна енергія (включаючи агробіопаливо, біомасу тощо) відносяться до тих видів відновлювальної енергетики, який насьогодні успішно впроваджуються на практиці, має відповідні наукові обгрунтування та дослідження, але у кількості виробленої енергії суттєво поступаються сонячній та вітровій енергетикам [3]. Однак інформація про них є невід’ємною та важливою складовою частиною усіх сучасних оглядів та проектів [4]. Щодо біопаливної енергетики (Biofuel Energy), то спостерігаються дуже близькі значення між $R_{1}$ (за цитуванням) і $R_{2}$ (за останні роки) 0,99 і 0,98 відповідно [5] ( $R=N_{\text {rel }} / N$ - частка релевантних публікацій відповідно тематики відновлювальної енергетики від їх загальної кількості). Це свідчить про чітку тематичну спрямованість таких публікацій.

Біоенергетика насьогодні у світі $€$ одним 3 невід’ємних і прогресивних напрямків відновлювальної енергетики. Хоча значно менша кількість робіт стосується біопаливної енергії у порівнянні із сонячною, вітровою чи гібридною енергією. Так за тегом «Biofuel Energy» hіндекс публікацій дорівнює 256 і $4 \%$ загальної кількості публікацій за тематикою відновлювальної енергетики $[2,5]$. Але існує досить потужна практична реалізація. Тобто, на ринку $є$ велика кількість гравців, які комерційно впроваджують ці напрямки, користуючись великими підтримками на рівні держав та використовуючи їх природний та виробничий потенціали. Тому й імпакти цієї невеликої у відсотках кількості публікацій достатньо високі.

Відсотковий вміст внеску саме статей із галузі матеріалознавства у біоенергетику, як розділу, який для цього напрямку найбільше відповідає фундаментальній природничій науці, становить (включаючи Chemical Engineering (хімічну інженерію)) 35,9\% [2]. Тобто, біоенергетика відноситься до технологічних сфер, яка має вагому наукову складову.

Певну статистику щодо публікацій світової наукової спільноти за тегом «Biofuel Energy» наведено у таблиці 1. Однозначними країнами лідерами щодо публікацій у сфері біопаливної енергетики є США та Китай. Кожна із цих держав має потужні дослідницькі центри. Тому їх 1a i 2-a позиції є очевидними. Індія, Великобританія, Німеччина та ін. - це країни, які обрали енергетичну безпеку як свій національний пріоритет.

Таблиця 1. Статистика кількості публікацій по країнах та провідних науково-дослідних центрах відповідно до тегу «Biofuel Energy» («Біопаливна енергія / енергетика»)

\begin{tabular}{|c|c|c|c|c|c|}
\hline \multirow{2}{*}{\multicolumn{2}{|c|}{ Країни-лідери }} & \multicolumn{4}{|c|}{ Провідні науково-дослідні центри } \\
\hline & & \multicolumn{2}{|c|}{ за кількістю публікацій } & \multicolumn{2}{|c|}{ за кількістю цитувань } \\
\hline 1.USA & США & 1.UC & Каліфорнійський & 1. Univ. of & Ун-т Юти, Солт- \\
\hline 2. China & Китай & Berkeley & ун-т в Берклі & Utah, Salt & Лейк-Сіті, США \\
\hline 3. India & Індія & & Центр с/г & Lake City, & \\
\hline 4.UK & Велико- & 2. USDA Agr. & досліджень МСГ & USA & Університетський \\
\hline 5 Germ & $\begin{array}{l}\text { британія } \\
\text { Німеччина }\end{array}$ & Res. Center & $\begin{array}{l}\text { США } \\
\text { МСГ США }\end{array}$ & $\begin{array}{l}\text { 2. Univ. } \\
\text { College Cork }\end{array}$ & $\begin{array}{l}\text { коледж Корка, } \\
\text { Корк. Іпланлія }\end{array}$ \\
\hline 6. Brazil & Бразилія & 3. US Deprt. & & Cork, Ireland & Гронінгенський \\
\hline 7. Italy & Італія & Agr. & Ун-т Сан-Паулу & 3. Univ. of & ун-т, Гронінген, \\
\hline 8. Canada & Канада & $\begin{array}{l}\text { 4. Univ. Sao } \\
\text { Paolo } \\
\text { 5. Oak Ridge } \\
\text { Nat. Lab. }\end{array}$ & $\begin{array}{l}\text { Оук-Ридзька } \\
\text { нац. лабораторія }\end{array}$ & $\begin{array}{l}\text { Groningen, } \\
\text { Groningen, } \\
\text { Netherlands }\end{array}$ & Нідерланди \\
\hline
\end{tabular}

Ситуація щодо науково-дослідних центрів, які займають провідні позиції за кількістю публікацій, дещо відмінна від рейтингу за державою. Існують центри, які є однозначними лідерами в енергетичних дослідженнях. Причому, це одночасно може бути і розробка політики щодо екологічних норм джерел енергії, і розробка принципово нових матеріалів та пристроїв. Тобто, існують організації, які здобули незаперечну позитивну репутацію (табл. 1, стовпчик 2): Каліфорнійський ун-т в Берклі, Центр сільськогосподарських досліджень Міністерства сільського господарства США, Університет Сан-Паулу, Оук-Ридзька національна лабораторія та ін.

Але ще цікавішим $є$ третій стовпчик табл. 1 , у якому наведено центри, які $є$ найбільш цитованими. Відбір проводився за найцитованішими дослідниками із цих центрів (наведено афіліацію найбільш визнаних вчених). У біоенергетиці перші три позиції займають заклади, що не входять у перелік організацій із стовпця 2. Тобто, загальна кількість публікацій авторів із

(C) Никируй Л.І., Замурусва О.В., Федосов В.С., Урбан О.А., Захарчук Д.А., Федосов С.А. 
закладів, що вказані у стовпці $3 €$ меншою, але саме вони є флагманами («засновником тенденцій»). І виявляється, що ці «засновники тенденцій» представляють організації не лише із США, Китаю, Індії, Німеччини, але й із Ірландії, Нідерландів, які не входять у перелік держав, наведених у стовпці 1 табл. 1. Тобто, якщо певна держава не входить до переліку тих країн, які видають найбільшу кількість публікацій, тим не менше, дослідники з них можуть претендувати на найвищі позиції у рангу світових вчених.

Найбільш цитовані публікації, пов'язані з біомасою та біопаливом, були опубліковані у таких журналах: Renewable and Sustainable Energy Reviews (h-індекс - 193), Biomass and Bioenergy (h-індекс - 143), Bioresource Technology (h-індекс - 229), Renewable Energy (h-індекс - 143), Energy (h-індекс - 146). Також за інформацією бази даних Scopus визначено найвидатніших та найвпливовіших вчених у галузі біоенергетики. Це Omer A.M. 3 Великобританії (має 122 публікації з біомаси як відновлюваного джерела енергіï), Pari L. 3 Італії (103 публікації) та Kaltschmitt М. з Німеччини (102 публікації).

Кількість робіт українських та польських науковців набагато менша ніж кількість публікацій світового наукового співтовариства. Економічна ситуація в країнах суттєво впливає на кількість публікацій. Нижче наведено короткий опис інформації, наявної в міжнародних наукових базах даних про стан досліджень у напрямку біоенергетики проведений у двох прикордонних країнах. Ці дві країни зараз реалізують бажання розвиватися разом і $є$ прикладом того, як можна створити конкурентне наукове середовище на кордоні ЄС. Для зручності проведення аналізу важливості наукових досліджень вченими з Польщі та України, зібрані дані узагальнені в таблиці 2.

Таблиця 2.

Порівняльна статистична характеристика досліджень України та Польщі, проведених у напрямку «Біоенергетика (енергія з біомаси та біопалива)»

\begin{tabular}{|c|c|c|}
\hline Україна & Порівняння & Польща \\
\hline 71 & $\begin{array}{c}\text { Кількість } \\
\text { публікацій }\end{array}$ & 324 \\
\hline 13 & h-індекс & 37 \\
\hline $\begin{array}{l}\text { - Nat. Univ. of Life and } \\
\text { Environmental Sciences of } \\
\text { Ukraine } \\
\text { - Nat. Univ. «Lviv Polytechnics» } \\
\text { - Taras Shevchenko Nat. Univ. of } \\
\text { Kyiv } \\
\text { - Vasyl Stefanyk Precarpathian } \\
\text { Nat. Univ. }\end{array}$ & $\begin{array}{c}\text { Провідні } \\
\text { установи } \\
\text { (5 позицій) }\end{array}$ & $\begin{array}{l}\text { - Polish Academy of Sciences } \\
\text { - Uniw. Jagielloński w Krakowie } \\
\text { - Uniw. Warminsko-Mazurski w } \\
\text { Olsztynie } \\
\text { - Wrocław Univ. of Science and } \\
\text { Technology } \\
\text { - Uniw. im. Adama Mickiewicza } \\
\text { w Poznaniu }\end{array}$ \\
\hline $\begin{array}{l}\text { - Energy } \\
\text { - Agricultural and Biological } \\
\text { Sciences } \\
\text { - Environmental Science } \\
\text { - Biochemistry, Genetics and } \\
\text { Molecular Biology } \\
\text { - Engineering }\end{array}$ & $\begin{array}{c}\text { Найбільше } \\
\text { представленні } \\
\text { наукові } \\
\text { напрямки }\end{array}$ & $\begin{array}{l}\text { - Biochemistry, Genetics and } \\
\text { Molecular Biology } \\
\text { - Agricultural and Biological } \\
\text { Sciences } \\
\text { - Environmental Science } \\
\text { - Energy }\end{array}$ \\
\hline $\begin{array}{l}\text { - European Commission } \\
\text { - Ministry of Education and } \\
\text { Science of Ukraine }\end{array}$ & $\begin{array}{c}\text { Найбільша } \\
\text { фінансова } \\
\text { підтримка }\end{array}$ & $\begin{array}{l}\text { - Narodowe Centrum Nauki } \\
\text { - Ministry of Higher Education }\end{array}$ \\
\hline $\begin{array}{l}\text { - Germany } \\
\text { - Italy }\end{array}$ & Країна-партнер & $\begin{array}{l}\text { - United States } \\
\text { - Germany }\end{array}$ \\
\hline
\end{tabular}

Аналіз публікацій [6] показує, що дослідження біоенергетики є дуже актуальними з точки зору поліпшення навколишнього середовища, а саме вивчення біокомпозитів (або біополімерів) як заміни пластиків, виробництва біодизеля. Найцікавішими відновлюваними джерелами енергії для регіону Польщі є відходи біомаси сільськогосподарського виробництва, які також корисні для поліпшення навколишнього середовища та медичних цілей. Однак найцікавішим $\epsilon$ виробництво біогазу $[7,8]$, що вимагає дешевої сільськогосподарської сировини. Огляд [7] $\epsilon$ найважливішим 3 точки зору розробки технологічних процесів для біогазу (1) виробництва, (2)

( ) Никируй Л.І., Замурусва О.В., Федосов В.С., Урбан О.А., Захарчук Д.А., Федосов С.А. 
обробки, (3) утилізації та (4) промислової організації (симбіозу). А враховуючи високу потужність біогазових установок у Польщі, увагу приділяли дослідженню якості компосту для виробництва якісного біогазу [8].

Оскільки біомаса доступна в якості побічного продукту багатьох промислових i сільськогосподарських процесів майже скрізь, іiі легко отримати i вона $\epsilon$ вуглецевонейтральним джерелом енергії, відповідно до економічного аналізу біоенергетики в Європі біомаса $є$ перспективним відновлювальним джерелом енергії з високим потенціалом росту.

Більшість робіт польських авторів присвячені загальним перспективам розвитку біомаси. Так, у [9] було проаналізовано найбільші установи, що виробляють біоетанол та біодизель. Проведено порівняльний аналіз різних поновлюваних джерел енергії для сільських територій. Вплив енергоефективності у виробництві біопалива на потенційне задоволення сільськогосподарської потреби в енергії досліджено в [10]. Математична модель показує результати виключення сільськогосподарських культур із виробництва продуктів харчування, спрямовані на задоволення енергетичних цілей. Представлений ряд продуктів, які можна отримати в сільськогосподарському виробництві та використовувати в енергетичних цілях. Проаналізовано потенційний обсяг сировини, яку можна отримати 3 сільського господарства Польщі для виробництва біогазу.

Дуже багато публікацій спрямовані на технічні характеристики виробництва біомаси. У [11] представлені результати дослідження технологій переробки біомаси верби та біомаси чорної сарани. Крім того, згідно з прогнозом на 2021 рік, приблизно 80 \% кінцевої енергії з поновлюваних джерел надходитиме з біомаси, і майже вся іï буде вироблятися за рахунок сільського господарства. Показано зміни в структурі використання біомаси. Таким чином, використання біомаси для опалення зменшується, а частка біомаси для електроенергії та біопалива збільшується. У той же час у публікаціях спостерігається тенденція щодо екологічності біоенергетики, зокрема, її внеску у зменшення парникового ефекту.

Ряд праць українських вчених також присвячені загальним тенденціям виробництва біоенергетики. Аналіз біологічних ресурсів для виробництва біопалив в Україні був зроблений у [12]. Аспекти переходу до агробіоенергетики в Україні, а також стратегії та рекомендації для різних зацікавлених сторін для полегшення цього переходу запропоновані в [13].

Позитивні тенденції біоенергетики підкреслюються в ряді досліджень. Орієнтовний енергетичний потенціал існуючих відходів біомаси становить близько 25 мільйонів тонн, а енергетичний потенціал біомаси, який можна вирощувати на невикористаних землях сільськогосподарського призначення, становить близько 13 мільйонів тонн. Проаналізовано ринки ріпаку України та Європейського Союзу, які є горизонтально інтегрованими. Автори [14] розраховували прибуток від біогазової установки для птахофабрики, а в [15] були наведені основні практичні кроки створення українського ринку біогазу.

Спільна публікація [16] підсумовує дослідження біоаерозолів, які проводились у 19722009 pp. У таких галузях сільського господарства України та Польщі: тваринницьких господарствах, кормах, виробництві біопалива з ріпаку тощо. У ряді інших спільних публікацій оцінено потенціал біомаси, отриманої від побічних продуктів рослинництва та розведення тварин, які можуть бути використані в енергетичних цілях.

Загалом h-індекси публікацій українських дослідників є значно нижчими за h-індекси науковців світу $[6,17]$. Для України практично без зміни у відсотковому співвідношенні від усієї кількості публікацій за тематикою відновлювальної енергетики залишилися кількість публікацій за тегом «Biofuel energy» (3 \% в Україні проти 4 \% у світі). Для кращого розуміння співвідношення між українськими, польськими досягненнями та існуючим станом публікацій у світі, побудовано діаграми, які демонструють відносні значення h-індексів та кількості публікацій (рис. 1). Нижчі значення демонструють вищий потенціал досягнень дослідників (зворотний характер).

Розглядаючи енергію біопалива (енергія з біомаси та біопалива) в Україні та Польщі, можна виділити певні спільні риси. Перш за все, співпраця польських та українських вчених, виражена через велику кількість спільних публікацій, що є пріоритетом обох країн. Також вчені обох країн успішно співпрацюють зі своїми колегами з Німеччини (табл. 2). Тобто є спільні дослідження як сусідніх держав, так і високотехнологічних, які володіють найсучаснішим обладнанням. Хоча практичний розвиток біоенергетики визначається виключно економічною ситуацією в аграрному секторі. 
Існує різниця в кількості (324 та 71 відповідно для Польщі та України) та «імпактфактору» (37 та 13 відповідно) публікацій у напрямку біоенергетики. Для більш ефективного аналізу визначаються їх нормалізовані залежності: $h_{n o r m}=h_{i} / N_{i}$, де $h_{i}-\mathrm{h}$-індекс публікацій у відповідному напрямку, $N_{i}$ - загальна кількість публікацій у цьому напрямку.

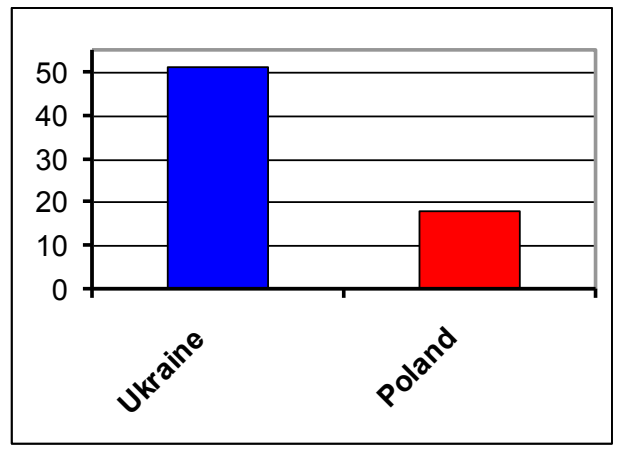

a

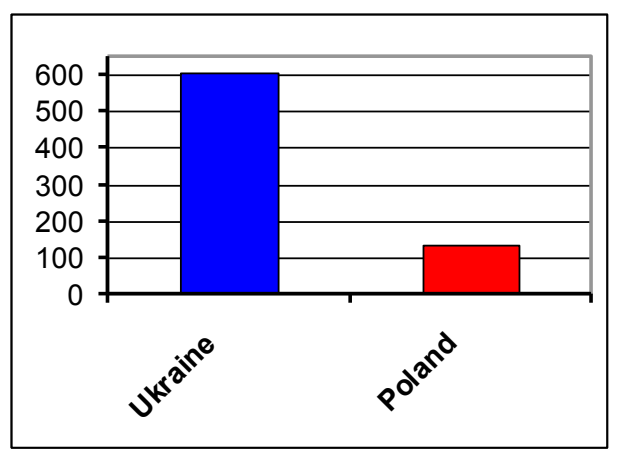

6

Рис. 1. Співвідношення (a) $\mathrm{h}$-індексів $\left(\mathrm{h}_{g l o b} / \mathrm{h}_{u k r}, \mathrm{~h}_{g l o b} / \mathrm{h}_{p o l}\right)$ та (б) кількості публікацій $\left(N_{g l o b} / N_{u k r}, N_{g l o b} / N_{p o l}\right)$ за напрямком «Біопаливна енергетика» (Biofuel energy) науковців України та Польщі до світових

Для «Біоенергетики» h-індекс польських вчених значно вищий. Це свідчить про стимулювання подібних досліджень на державному рівні в Польщі та надто малу підтримку 3 боку України на цьому етапі. Однак, враховуючи, що публікації українських вчених почали публікуватися в цій галузі за останні кілька років, і завдяки партнерству між науковими установами обох країн можна передбачити збільшення як кількості, так і якості таких матеріалів у межах наступні 5 років.

Висновки. Для ефективного розвитку та впровадження біопаливної енергетики необхідно враховувати одночасно різні фактори: економічний та наявність інвестицій, розробки нових, екологічно чистих та ефективних досліджень i створення можливостей для їх впровадження.

Якість досліджень можна довести на основі передових наукових публікацій у рецензованих журналах. Кількість та вплив таких наукових публікацій свідчать про потенціал наукових колективів, їх актуальність та можливість впровадження.

Різниця майже в 2 рази нормалізованого h-індексу (відповідно 9 і 5) за напрямом «Біоенергетика» свідчить про значно більший прогрес польських вчених у цьому напрямку. Прикладні дослідження, які потребують складних установок для їх тестування або дорогого імітаційного програмного забезпечення, ефективніше впроваджуються в країнах ЄС.

\section{Інформаційні джерела}

1. Yakubiv V., Zhuk O., Prodanova I. Model of region's balanced agricultural development using the biomass energy potential. Economic Annals-XXI. 2014. № 3-4(1). P. 86-89.

2. Wisz G., Nykyruy L., Yakubiv V., Hryhoruk I., Yavorskyi R. Impact of Advanced Research on Development of Renewable Energy Policy: Case of Ukraine. Int. J. Renewable Energy Res. 2018. Vol. 8, № 4. P. 2367-2384.

3. Ehrlich R., Geller H.A. Renewable Energy, 2nd Ed.: A First Course. CRC Press, 2017. $490 \mathrm{p}$.

4. Energy DG, European Commission. EU, Energy in Figures, Statistical Pocketbook 2017. Brussels: Publications Office of the European Union, 2017. 265 p.

5. Nykyruy L.I., Zamurujeva O.V., Urban O.A., Fedosov S.A. The Impact of Scientific Research on the Development of Renewable Energy. Perspective Technologies and Devices. 2020. № 16. P. 82-91.

6. Nykyruy L., Yakubiv V., Wisz G., Hryhoruk I., Zapukhlyak Z., Yavorskyi R. Renewable Energy in Ukraine - Poland Region: Comparison, Critical Analysis and Opportunities. In Renewable Energy-Resources, Challenges and Applications. IntechOpen. 2020. 
7. Budzianowski WM. A review of potential innovations for production, conditioning and utilization of biogas with multiple-criteria assessment. Renewable and Sustainable Energy Rev. 2016. Vol. 54. P. 1148-1171.

8. Godlewska P., Schmidt H.P., Ok Y.S., Oleszczuk P. Biochar for composting improvement and contaminants reduction. A review. Bioresour. Technol. 2017. Vol. 246. P. 193-202.

9. Igliński B., Iglińska A., Kujawski W., Buczkowski R., Cichosz M. Bioenergy in Poland. Renewable and Sustainable Energy Rev. 2011. Vol. 15, № 6. P. 2999-3007.

10. Wasiak A.L. Effect of Biofuel Production on Sustainability of Agriculture. Procedia Eng. 2017. Vol. 182. P. 739-746.

11. Wrobel M., Mudryk K., Jewiarz M., Knapczyk A. Impact of raw material properties and agglomeration pressure on selected parmeters of granulates obtained from willow and black locust biomass. 17th Int. Sci. Conf. Engineering for Rural Development, 23.-25.05.2018, Jelgava. 2018. P. 1933-1838.

12. Panchuk M., Kryshtopa S., Shlapak L., et al. Main trends of biofuels production in Ukraine. Transport Problems. 2017. Vol. 12, № 4. P. 15-26.

13. Voytenko Y. Pathways for agro-bioenergy transition in Ukraine. Biofuels, Bioproducts and Biorefining. 2012. Vol. 6, № 2. P. 124-134.

14. Yevdokimov Y., Chygryn O., Pimonenko T., Lyulyov O. Biogas as an alternative energy resource for Ukrainian companies: EU experience. Innovative Marketing. 2018. Vol. 14, № 2. P. 7-15.

15. Cebula J., Chygryn O., Chayen S.V., Pimonenko T. Biogas as an alternative energy source in Ukraine and Israel: Current issues and benefits. Int. J. Environ. Technol. Management. 2018. Vol. 21, № 5/6. P. 421-438.

16. Tsapko V.G., Chudnovets A.J., Sterenbogen M.J., et al. Exposure to bioaerosols in the selected agricultural facilities of the Ukraine and Poland - a review. Ann. Agric. Environ. Med. 2011. Vol. 18, № 1. P. 19-27.

17. Nykyruy L., Zamurujeva O., Fedosov V., Biruk O., Fedosov S. Scientific and Technical Progress of Renewable Energy Development in Ukraine. Scientific Notes. 2020. № 70. P. 18-26.

Никируй Л.И. ${ }^{1}$, Замуруева О.В. ${ }^{2}$, Федосов В.С. ${ }^{2}$, Урбан О.А. ${ }^{3}$, Захарчук Д.А. ${ }^{3}$, Федосов С.А. ${ }^{2}$ ${ }^{1}$ Прикарпатский национальный университет имени Василия Стефаника

${ }^{2}$ Волынский национальный университет имени Леси Украинки

${ }^{3}$ Луцкий национальный технический университет

\section{ПЕРСПЕКТИВНЫЕ ТЕХНОЛОГИИ БИОТОПЛИВНОЙ ЭНЕРГЕТИКИ}

В работе проанализированы публикаиии авторитетных мировых ученых и из двух соседних стран - Украины и Польши в области биотопливной энергетики, чтобы найти закономерности развития этого направления в мире и каждом из государств в частности, а также определить перспективы для совместных исследований. Анализ основывается на результатах данных, опубликованных в международных научных базах данных Web of Science u Scopus. Выявлено состояние развития отрасли в мире, Украине и Польше, проанализировань как теоретические, так и прикладные исследования, направленные на практическое применение.

Ключевые слова: возобновляемые источники энергии, энергия биотоплива, биотопливо, биомасса, Украина, Польша,

Nykyruy L.I. ${ }^{1}$, Zamurujeva O.V. ${ }^{2}$, Fedosov V.S. ${ }^{2}$, Urban O.A. ${ }^{3}$, Zakharchuk D.A. ${ }^{3}$, Fedosov S.A. ${ }^{2}$ ${ }^{1}$ Vasyl Stefanyk Precarpathian National University

${ }^{2}$ Lesya Ukrainka Volyn National University

${ }^{3}$ Lutsk National Technical University

\section{PROMISING BIOFUEL ENERGY TECHNOLOGIES}

The paper analyzes the publications of authoritative world scientists and from two neighboring countries - Ukraine and Poland in the fields of biofuel energy in order to find patterns in the development of this direction in the world and in each of the states in particular, as well as to determine the prospects for joint research. The analysis is based on the results of data published in the international scientific databases Web of Science and Scopus. The state of development of the industry in the world, in Ukraine and Poland is revealed, both theoretical and applied research aimed at practical application are analyzed.

Keywords: renewable energy, biofuel energy, biofuels, biomass, $h$-index, Poland, Ukraine. 